DOI

\title{
РОЛЬ НЕКОТОРЫХ РЕГУЛЯТОРНЫХ ЦИТОКИНОВ В ИММУНОПАТОГЕНЕЗЕ ЭКЗОГЕННЫХ АЛЛЕРГИЧЕСКИХ АЛЬВЕОЛИТОВ
}

\author{
○ш. Х. Зиядуллаев, Н. Р. Аралов, Ж. А. Исмаилов, М. М. Рахимов, С. Ж. Юлдашев \\ Самаркандский государственный медицинский институт, Самарканд
}

PЕзЮМЕ. Представлены результаты изучения сывороточной концентрации цитокинов IL-8 и IL-12, участвующих в регуляции иммунного ответа у больных экзогенным аллергическим альвеолитом. Полученные нами данные показали разнонаправленные изменения в продукции цитокинов в зависимости от стадий заболевания. Так, ЭАА в период острого течения сопровождается наиболее выраженными изменениями со стороны провоспалительного цитокина IL-8, обеспечивающего активное перемещение различных видов иммунных клеток в очаг воспаления, а период подострого и хронического аллергического воспаления у больных с ЭАA сопровождается выраженными изменениями в продукции цитокина IL-12, регулирующего клеточный иммУнныЙ ответ.

КЛЮЧЕВЫЕ СЛОВА: экзогенные аллергические альвеолиты; цитокины; иммунопатогенез.

Вступление. Экзогенные аллергические альвеолиты (ЭАА) - группа заболеваний, характеризующихся аллергическим диффузным поражением альвеолярных и интерстициальных структур легких и возникающих в ответ на повторную ингаляцию антигенов пыли органического и неорганического происхождения и применение лекарственных средств. По данным ВОЗ, группа заболеваний под этим названием выявляется у 3 \% пульмонологических больных и достигает 42 случая на 100000 населения [2, 4]. ЭАА справедливо считают иммунопатологическим заболеванием, в развитии которого ведущая роль принадлежит аллергическим реакциям 3-го и 4-го типов [1]. На сегодняшний день одним из важнейших направлений иммунологии стала разработка концепции иммуноцитокиновой сети - системы гуморальных посредников между иммунокомпетентными и другими клетками, вовлеченными в иммунные реакции, которые осуществляют последовательную смену этапов иммунологического ответа, кооперацию между факторами неспецифической защиты и иммунитета, реакции ранней и поздней фаз воспаления, переключение классов синтезируемых антител [3]. Среди большинства известных цитокинов большое значение придается цитокинам интерлейкинам-8 и -12, оказывающим воздействие на активное перемещение различных видов лейкоцитов и других клеток, а также регулирующим клеточный иммунитет при различных воспалительных процессах.

Цель работы - изучить концентрацию некоторых цитокинов, участвующих в регуляции иммунного ответа у больных экзогенным аллергическим альвеолитом (ЭАА), в частности продукцию IL-8 и IL-12.

Материал и методы исследования. Для достижения цели были обследованы 60 больных
ЭАА с различным течением заболевания, находившихся на стационарном лечении в пульмонологическом отделении Самаркандского медицинского объединения. Верификация диагноза проводилась в соответствии с международной классификацией ВОЗ (МКБ-10, рубрика Ј 67). Все больные ЭАА в зависимости от стадии были поделены на 3 группы: 1 группа - острая, 2 группа - подострая, 3 группа - хроническая стадия заболевания. Все клинические и биохимические лабораторные обследования проведены стандартизованными методами. Определение уровней IL-8 и IL-12 в сыворотке крови проводили методом иммуноферментного анализа с использованием тест-системы для ИФА «ИФА-ИЛ-8» и «ИФА-ИЛ-12» (ЗАО «Вектор-Бест», Россия). Контрольную группу составили 15 практически здоровых лиц. Полученные данные подвергали статистической обработке на персональном компьютере по программам, разработанным в пакеTе EXCEL с использованием библиотеки статистических функций.

Результаты и обсуждение. Для уточнения иммунологических основ патогенеза ЭАА нами изучена концентрация некоторых цитокинов, участвующих в регуляции иммунного ответа у больных ЭАА, в частности, продукция IL-8 и IL-12. Анализ содержания IL-8 у обследованных нами больных ЭАА показал, что уровень его в общей группе исследованных пациентов составляет $(38,4 \pm 2,5)$ пг/мл (рис. 1) и существенно превышает значения, характерные для практически здоровых лиц $((18,1 \pm 1,8)$ пг/мл, $p<0,01)$.

При сопоставлении изучаемых показателей в группах больных с различным течением заболевания выявлено, что наиболее высокий уровень IL-8 регистрируется среди пациентов с острым течением ЭАA. В данной группе содержание IL-8 coставляет $(48,1 \pm 4,31)$ пг/мл, что более чем в 3 раза 
Огляди літератури, оригінальні дослідження, погляд на проблему

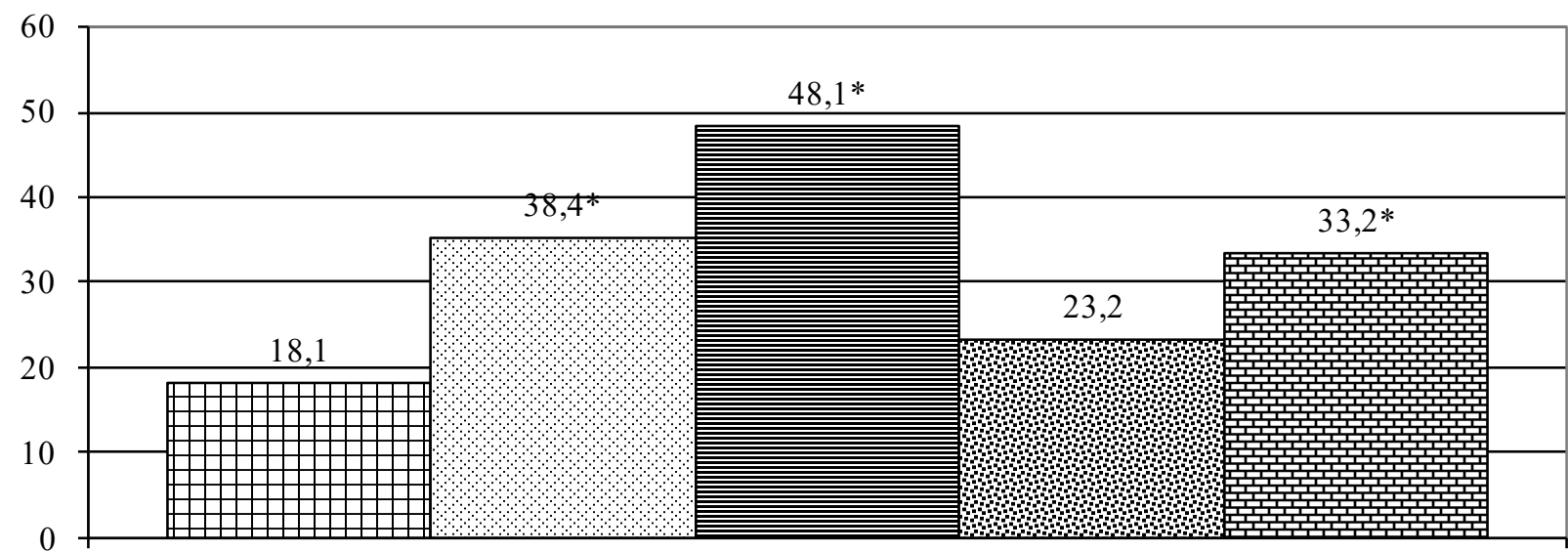

IL-8
$\boxplus \Pi 3$
๑Больные ЭАА
国Э ЭA
回 ПЭАА
$\boxplus \mathrm{X} Э \mathrm{AA}$

Рис. 1. Уровень IL-8 у больных в зависимости от фазы течения ЭАA.

Примечание: *- р<0,05 - достоверность различий в сравнении с показателями группы практически здоровых лиц.

выше показателей контрольной группы. Напротив, уровень IL-8 был относительно низким при хроническом ЭАА, имея промежуточные значения у пациентов с подострым ЭАА.

Следовательно, полученные результаты указывают на то, что все исследованные клинические варианты ЭАА характеризуются увеличением содержания в сыворотке крови больных IL8, однако при этом превалирование гуморальных аллергических механизмов в патогенезе заболевания сопровождается наиболее высоким уровнем данного провоспалительного цитокина, достоверно отличающимся при остром ЭАА $((48,1 \pm 4,31)$ против $(18,1 \pm 1,81)$ пг/мл, $\mathrm{p}<0,05)$.

При исследовании содержания в сыворотке крови IL-12 у обследованного нами контингента пациентов выявлены следующие особенности данного показателя в зависимости от фазы ЭАА (табл. 1).

При анализе полученных нами результатов было установлено, что у пациентов с ЭАА уровень IL-12 составляет $(97,9 \pm 4,31)$ пг/мл, значительно превышая показатели группы практически здоровых лиц $((64,8 \pm 8,7)$ пг/мл, р<0,01). Как оказалось, уровень IL-12 значительно колеблется в сравниваемых нами группах больных с разной стадией ЭАА. Наиболее высоким этот показатель был у пациентов в хронической стадии ЭАА $((159,9 \pm 12,0)$ пг/мл), достоверно отличаясь от параметров группы здоровых $((64,8 \pm 8,7)$ пг/мл; $\mathrm{p}<0,01)$ и больных с острым течением ЭАА $((111,6 \pm 10,2)$ пг/мл; p<0,01). Также у больных с подострым ЭАA уровень IL-12 более чем в два раза превышал показатели лиц контрольной группы $(p<0,02)$.

Таким образом, наиболее высокий уровень изучаемого параметра отмечается у больных ЭАА в хронической стадии, что выделяет эту группу среди общей группы изучаемых пациентов с ЭАА, а также отличает ее от двух сравниваемых групп с острой и подострой стадиями заболевания.

Учитывая описанные в литературе семейные случаи восприимчивости к заболеванию мы изучили иммунологические изменения у 19 больных с семейной отягощенностью по ЭАА. Как видно из таблицы 2, при анализе иммунологических показателей у больных исследуемой группы отмечается повышение IL-8 $((35,2 \pm 4,12)$ пг/мл) по сравнению с группой практически здоровых $((18,1 \pm 1,81) п г / м л, p<0,02)$.

Таблица 1. Уровень IL-12 в зависимости от стадии ЭАA

\begin{tabular}{|l|c|}
\hline \multicolumn{1}{|c|}{ Группы обследованных } & $\mathrm{IL}-12$ (пг/мл) \\
\hline Практически здоровые $(n=15)$ & $64,8 \pm 8,7$ \\
\hline Общая группа $(n=45)$ & $97,9 \pm 4,3^{*}$ \\
\hline Острый ЭАА ( $n=17)$ & $111,6 \pm 10,2^{*}$ \\
\hline Подострый ЭАА $(n=11)$ & $141,6 \pm 10,2^{*}$ \\
\hline Хронический ЭАА $(n=17)$ & $159,9 \pm 12,0^{*}$ \\
\hline
\end{tabular}

Примечание: * - p<0,05 - достоверность различий в сравнении с показателями группы практически здоровых лиц. 
Огляди літератури, оригінальні дослідження, погляд на проблему

Таблица 2. Цитокиновый статус у больных ЭАА с семейной отягощенностью

\begin{tabular}{|c|c|c|}
\hline Группы обследованных & IL-12 (пг/мл) & IL-8 (пг/мл) \\
\hline Практически здоровые (n=15) & $64,8 \pm 8,7$ & $18,1 \pm 1,81$ \\
\hline Общая группа (n=45) & $97,9 \pm 4,31 *$ & $38,4 \pm 2,5^{*}$ \\
\hline Больные ЭАА с семейной отягощенностью $(n=19)$ & $60,9 \pm 6,8$ & $35,2 \pm 4,12 *$ \\
\hline Больные ЭАА без семейной отягощенности $(\mathrm{n}=26)$ & $62,2 \pm 5,8$ & $28,1 \pm 4,9 *$ \\
\hline
\end{tabular}

Примечание. *- p<0,05 - достоверность различий в сравнении с показателями группы практически здоровых лиц.

Уровень IL-8 у больных ЭАA с семейной отягощенностью $(35,2 \pm 4,12)$ пг/мл превышал $(28,1 \pm$ 4,9 пг/мл), а уровень IL-12, составляя $(60,9 \pm 6,8)$ пг/мл, имел низкие значения, по сравнению с лицами без наследственной отягощенности $((62,2 \pm 5,8) \pi г /$ мл). При сравнении больных ЭАА общей группы и больных без наследственной отягощенности мы выявили, что уровень исследуемых показателей не достигает достоверной статистической значимости.

Выводы. Результаты исследования уровней продукции IL-8 и IL-12 показали, что ЭАА в период острого течения сопровождается наиболее вы- раженными изменениями со стороны провоспалительного цитокина IL-8, обеспечивающего активное перемещение различных видов имунных клеток в очаг воспаления, а период подострого и хронического аллергического воспаления сопровождался выраженными изменениями в продукции цитокинов, регулирующих клеточный иммунный ответ, в частности IL-12 у больных с ЭАА. Следовательно, полученные нами данные свидетельствуют о том, что у больных ЭАА отмечаются разнонаправленные изменения в продукции цитокинов в зависимости от стадий заболевания.

\section{ЛИТЕРАТУРА}

1. Драник Г. Н. Клиническая иммунология и аллергология. - М. : Мед. информ. Агентство, 2003. - 392 с.

2. Интерстициальные болезни легких : практическое руководство / под ред. Н. А. Мухина. - М. : Литтерра, 2007.

3. Fiseselmann J. F. Respiratory diseases /
J. F. Fiseselmann, H. B/ Richerson // Basic and Clinical Immunology. - 8th ed. / ed. by D. P. Stites, Al. Terr, T. G. Parslow. - Norwalk, CT : Appleton \& Lange, 1994. - P. 528-540.

4. Interstitial Lung Diseases / Ed. Olivieri D., du Bois R. M. ERS Monograph. V.5. Monograph 14. L., 2000

\section{REFERENCES}

1. Dranyk, H. N. (2003). Klinicheskaya immunologiia $i$ allerhologiia [Clinical immunology and allergology]. Moscow. Med. inform. ahentstvo [in Russian].

2. Mukhyna, N.A. (Eds.) (2007). Interstytsyalnye bolezni lehkykh: prakticheskoe rukovodstvo [Interstitial lung disease: practical guidance]. Lytterra [in Russian].
3. Fiseselmann, J.F., \& Richerson, H.B. (1994). Respiratory diseases: Basic and Clinical Immunology. Norwalk, CT: Appleton \& Lange.

4. Olivieri, D., \& Bois, R.M. (Eds.) (2000). Interstitial Lung Diseases. Monograph 14.

\title{
РОЛЬ ДЕЯКИХ РЕГУЛЯТОРНИХ ЦИТОКІНІВ В ІМУНОПАТОГЕНЕЗІ ЕКЗОГЕННИХ АЛЕРГІЧНИХ АЛЬВЕОЛІТІВ
}

\author{
๑Ш. Х. Зіядуллаев, Н. Р. Аралов, Ж. А. Ісмаїлов, М. М. Рахімов, С. Ж. Юлдашев
} Самаркандський державний медичний інститут, Самарканд

PЕзЮМЕ. Представлено результати вивчення сироваткової концентрації цитокінів IL-8 i IL-12, що беруть участь в регуляції імунної відповіді у хворих на екзогенний алергічний альвеоліт. Отримані нами дані показали 
Огляди літератури, оригінальні дослідження, погляд на проблему

різнонаправлені зміни в продукції цитокінів залежно від стадії захворювання. Так, ЕАА в період гострого перебігу супроводжується найвираженішими змінами з боку прозапальних цитокінів IL-8, що забезпечує активне переміщення різних видів імунних клітин у вогнище запалення, а період підгострого і хронічного алергічного запалення у хворих з ЕAA супроводжується вираженими змінами продукції цитокіну IL-12, що регулює клітинну імунну відповідь.

КлючОВІ СлОВА: екзогенні алергічні альвеоліти; цитокіни; імунопатогенез.

\section{THE ROLE OF CERTAIN REGULATORY CYTOKINES IN THE IMMUNOPATHOGENESIS OF EXTRINSIC ALLERGIC ALVEOLITIS}

@Sh. Kh. Ziyadullaev, N. R. Aralov, J. A. Ismailov, M. M. Rahimov, S. J. Yuldahev Samarkand State Medical Institute, Uzbekistan

SUMMARY. The article adduces the results of the study serum concentration cytokines IL- 8 and IL-12, involved in the regulation of the immune response in patients with extrinsic allergic alveolitis. The data obtained by us showed differently directed changes in the production of cytokines, depending on the stages of the disease. So, EAA during the acute course is accompanied by the most pronounced changes from the proinflammatory cytokine IL-8, providing the active movement of various types of immune cells in the focus of inflammation, and the period of subacute and chronic allergic inflammation in patients with EAA is accompanied by pronounced changes in the production of IL-12 cytokine regulating the cellular immune response.

KEY WORDS: extrinsic allergic alveolitis; cytokines; immunopathogenesis. 